
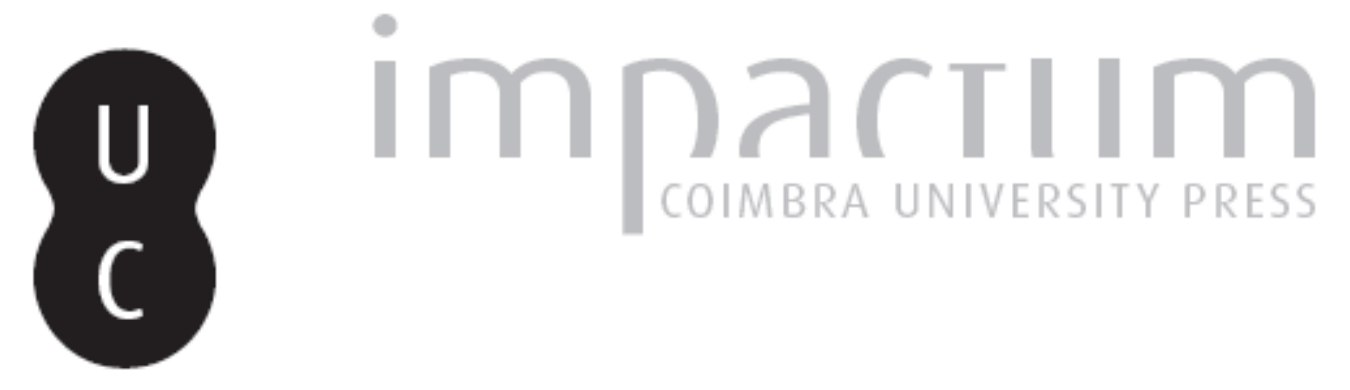

Higiene, doença e morte no recolhimento de Santa Maria Madalena de Braga (século
XVIII))

Autor(es): $\quad$ Araújo, Maria Marta Lobo de

Publicado por: Imprensa da Universidade de Coimbra

URL persistente:

URI:http://hdl.handle.net/10316.2/40692

DOI:

DOI:https://doi.org/10.14195/0870-4147_47_15

Accessed : $\quad$ 26-Apr-2023 14:12:37

A navegação consulta e descarregamento dos títulos inseridos nas Bibliotecas Digitais UC Digitalis, UC Pombalina e UC Impactum, pressupõem a aceitação plena e sem reservas dos Termos e Condições de Uso destas Bibliotecas Digitais, disponíveis em https://digitalis.uc.pt/pt-pt/termos.

Conforme exposto nos referidos Termos e Condições de Uso, o descarregamento de títulos de acesso restrito requer uma licença válida de autorização devendo o utilizador aceder ao(s) documento(s) a partir de um endereço de IP da instituição detentora da supramencionada licença.

Ao utilizador é apenas permitido o descarregamento para uso pessoal, pelo que o emprego do(s) título(s) descarregado(s) para outro fim, designadamente comercial, carece de autorização do respetivo autor ou editor da obra.

Na medida em que todas as obras da UC Digitalis se encontram protegidas pelo Código do Direito de Autor e Direitos Conexos e demais legislação aplicável, toda a cópia, parcial ou total, deste documento, nos casos em que é legalmente admitida, deverá conter ou fazer-se acompanhar por este aviso.

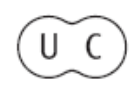




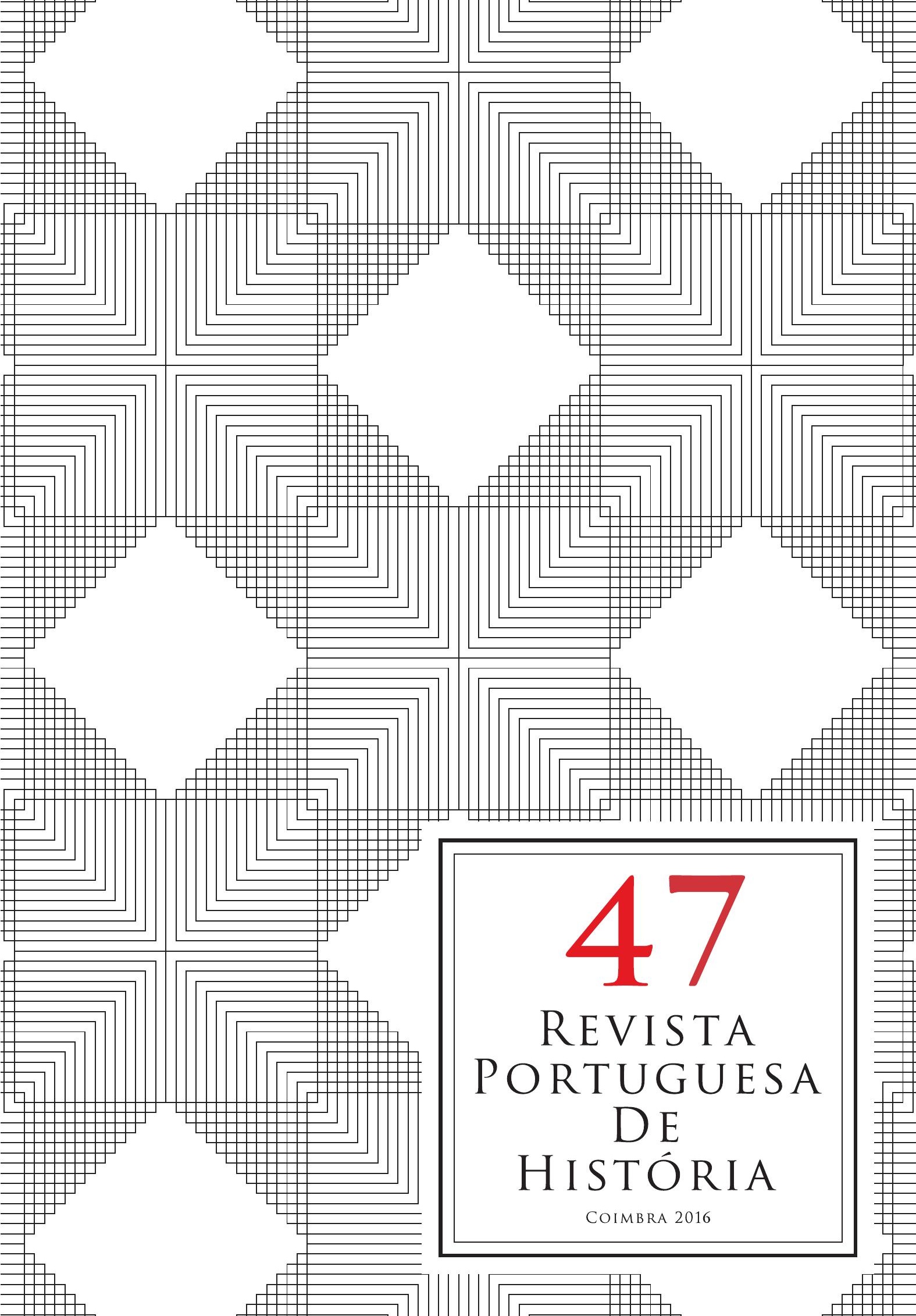




\title{
Higiene, doença e morte no recolhimento de Santa Maria Madalena de Braga (século XVIII)
}

\author{
Hygiene, disease and death in the "Recolhimento" \\ of St. Mary Magdalene de Braga (18th century)
}

\author{
Maria Marta Lobo de AraúJo \\ Departamento de História da Universidade do Minho (Lab2PT) \\ martalobo@ies.uminho.pt
}

Texto recebido em/Text submitted on: 31/01/2016

Texto aprovado em/Text approved on: 22/06/2016

\section{Resumo:}

Neste trabalho analisamos as práticas de higiene, a doença e a morte no recolhimento de Santa Maria Madalena ao longo do século XVIII, realçando alguns aspetos menos trabalhados na bibliografia existente sobre estas instituições.

Considerada a especificidade da instituição, cuidar da higiene e da saúde das suas internadas era fundamental para preservar a saúde da comunidade. Os procedimentos de higiene e a atitude perante a doença integram a nossa análise, ao mesmo tempo, que refletimos sobre a maneira como se preparavam e enfrentavam a morte. Neste campo, sublinhamos aspetos como os sacramentos, os acompanhamentos, os ofícios divinos e o local de sepultura.

\section{Palavras-chaves:}

Recolhimento de Santa Maria Madalena; Braga; Higiene; Doença e morte.

\section{Abstract:}

This study analyzes the hygiene practices, disease and death in the Recolhimento of St. Mary Magdalene during the 18th century, highlighting some aspects less worked in the existing literature on these institutions.

Considered the specific nature of the institution, taking care of hygiene and health of their admitted it was essential to preserve the health of the community. Hygiene procedures and the attitude towards the disease are part of our analysis, at the same time, we reflect on how they prepared and faced death. In this field, we emphasize aspects such as the sacraments, the accompaniments, the divine offices and place of burial.

Keywords:

Recolhimento of St. Mary Magdalene; Braga; Hygiene; Disease and death. 


\section{Introdução}

Fundado em 1720, mas com abertura dois anos após, o recolhimento de Santa Madalena é obra do arcebispo D. Rodrigo de Moura Teles (1704-1728) e destinava-se a acolher 12 mulheres, que tivessem caído em perdição, manchando a sua honra e quisessem, através da penitência, dar um novo rumo à vida. Estava dotado de uma regente, que dirigia a instituição e de uma porteira que guardava a porta principal da casa. Todas estas internadas eram suportadas pela Mitra, mas o recolhimento acolhia também supranumerárias, que tinham de pagar as despesas inerentes à sua estadia.

À medida que o século foi avançando, a procura da instituição cresceu, conhecendo-se na segunda metade o momento com mais internamentos. A este facto não terá sido alheiro o crescimento demográfico da cidade ao longo do século XVIII e a vontade de muitas mulheres se subtraírem ao poder paternal ou ao de outros familiares. Sublinhe-se que o recolhimento recebia mulheres da cidade, mas também de todo o Norte do reino e que foram as supranumerárias que fizeram aumentar o volume de internadas.

As condições de vida das que já eram pobres, condição agravada em muitos momentos pela subida do custo de vida, e a falta de rendimentos empurravam muitas vezes as mulheres para a prostituição ${ }^{1}$. Ser mulher pública era considerado o mesmo que prostituta, por frequentar o mundo masculino, que não era o seu². Era preciso tirá-las da vida pública para deixarem de servir de exemplo a outras mulheres ${ }^{3}$. No mundo católico, mas também no protestante, procurou-se controlar e enquadrar as prostitutas ${ }^{4}$. A estadia paga pela Mitra às do número procurava retirá-las do pecado e transformá-las em mulheres penitentes ${ }^{5}$.

O ideal de mulher honrada era ser submissa, humilde, devota e obediente. Porém, quer a igreja católica, quer a literatura moralista faziam acreditar que a mulher precisava de ser controlada para não cair em pecado. Quando a família

${ }^{1}$ Maria E. Monzón, “Marginalidad y prostitución”, in Isabel Morant (dir.), M. Ortega, A. Lavrin y P. Pérez Cantó (coords.), Historia de las mujeres en España y América Latina. El mundo moderno, Madrid, Cátedra, 2005, p. 379-385.

${ }^{2}$ Ana Sixto Barcia, Mujeres y cultura letrada en la Edad Moderna, Santiago de Compostela, Universidade de Santiago de Compostela, 2015, p. 571, tese de doutoramento policopiada.

${ }^{3}$ Laurinda, Abreu, O poder e os pobres. As dinâmicas políticas e sociais da pobreza e da assistência em Portugal (Séculos XVI-XVIII), Lisboa, Gradiva, 2014, p. 217-218.

${ }^{4}$ Scarlet Beauvalet-Boutouyrie, Les femmes à l'époque moderne (XVIe-XVIIIe siècles), Paris, Belin, 2003, p. 231.

${ }^{5}$ Jacques Depauw, Spiritualité et pauvreté a Paris au XVIIe siècle, Paris, Boutique de l'Histoire, 1999, p. 134. 
não o fazia e manchavam a sua honra, os recolhimentos, destinados a recebê-las e a convertê-las, constituíam uma opção.

O recolhimento em estudo era uma instituição de clausura, dotado de regulamentos desde a sua inauguração, instrumento normativo que regulava a vida de todas as internadas. Sujeitas a uma vigilância constante, quer fossem as do número ${ }^{6}$, ou as supranumerárias, todas estavam obrigadas a um programa intenso de conversão interior e ao trabalho. As orações individuais e em grupo, a oração vocal e mental, as idas ao coro, a participação em missas, as leituras espirituais, o exame de consciência diário, o jejum, a abstinência e as disciplinas em dias certos do ano compunham a programa espiritual a que se comprometiam quando ingressavam. Mas o trabalho na casa do lavor era outra parte importante da penitência a que se sujeitavam, por terem cometido o pecado da carne. Era através da clausura e da penitência que as mulheres se afastavam do perigo e sofriam o castigo de terem errado ${ }^{7}$.

Muito pouco tempo ficava para se recrearem. Apenas alguns momentos ao longo do dia para passearem na cerca, conversar de forma honesta com as companheiras ou continuarem alguns trabalhos de mãos nas celas e/ou na varanda.

A ligação com o exterior estava vedada e só era possível através das rodas e dos ralos. Mesmo assim, acontecia apenas quando a regente autorizava e a porteira vigiava.

$\mathrm{Na}$ igreja católica, e de acordo com as suas diretivas, cabia ao confessor vigiar a prática do sexo, assunto que devia manter discreto. O sexo devia ser praticado apenas com vista à procriação. Porém, as mulheres por serem consideradas fracas e serem seduzidas muitas vezes pelo Diabo, acabavam por cair na tentação e pecar ${ }^{8}$.

No estrangeiro e em Portugal o avanço feito nos últimos anos no campo da história das mulheres é inegável e expressa-se num conjunto de iniciativas e trabalhos de reputado valor. Estamos, porém, conscientes das grandes diferenças existentes em termos de tratamento do tema no nosso país e, por

${ }^{6}$ As 12 a quem a Mitra pagava todas as despesas inerentes ao seu internamento. Não existia número para as supranumerárias. Estas eram mulheres que aqui eram colocadas pelos maridos ou pelos pais para preservarem as suas virtudes, normalmente durante algum tempo. No caso das viúvas tratava-se de uma decisão pessoal.

${ }^{7}$ Maria Antónia Lopes, "Dominando corpos e consciências em recolhimentos portugueses (séculos XVII-XIX)", in Laureano M. Rubio Pérez (coord.), Instituciones y centros de reclusión colectiva. Formas y claves de una respuesta social (s. XVI-XX), León, Universidad de León, 2012, p. 107-118.

${ }^{8}$ Guy Bechtel, A Carne, o Diabo e o Confessor, Lisboa, Dom Quixote, 1998, p. 131. 
exemplo, na vizinha Espanha, onde o desenvolvimento temático atingiu outras dimensões ${ }^{9}$. Na verdade, os trabalhos levados a cabo na Espanha nas últimas duas décadas são bem elucidativos do interesse que a temática alcançou junto dos investigadores ${ }^{10}$.

Em Portugal, apesar de ainda não existir uma História das Mulheres, a historiografia tem-lhe dado destaque e trazido o assunto para a ordem do dia. Congressos, seminários, conferências e trabalhos científicos são demonstrativos do percurso feito ${ }^{11}$. Neste itinerário de investigação, as mulheres pobres e as que viviam em regime de clausura têm assumido um maior destaque. Porém, apesar de nas últimas décadas os recolhimentos terem servido de objeto de estudo a vários investigadores no nosso país, dando realce à vida das mulheres em clausura, nem sempre contemplam os aspetos que nos propomos trabalhar. Por

\footnotetext{
${ }^{9}$ Pela proximidade, sublinhamos o caso espanhol.

${ }^{10}$ Citam-se, entre outros, Ofelia Rey Castelao; Serrana Rial García, Historia de las mujeres en Galicia. Siglos XVI al XIX, Santiago de Compostela, Nigratrea, 2009; Serrana Rial G., Mujer y actividad económica en la Galicia moderna: la inserción de las mujeres en la producción económica rural y urbana, Santiago, 2002; "Solas y pobres: las mujeres de las ciudades de Galicia ante la marginalidad y la pobreza", Semata, 16 (2004) p. 301-331; Ofelia Rey Castelao, "La historia de las mujeres en Galicia. Un estado de la cuestión (1988-2008)", Minius, 17 (2009) p. 191-234; "Mujer y sociedad en la Galicia del Antiguo Régimen", Obradoiro de Historia Moderna, n. 3 (1994) p. 63; Angela Atienza L., "De beaterios a conventos: nuevas perspectivas sobre el mundo de las beatas en la España Moderna", Historia Social, 57 (2007) p. 145-168; M. L. Candaú C., "Disciplinamiento católico e identidad de género. Mujeres, sensualidad y penitencia en la España moderna", Manuscrits: Revista d'história moderna, 25 (2007) p. 211-237; María V. López-Cordón; Montsserrat Carbonel, (eds.), História de la mujer e História del matrimónio, Murcia, Universidad de Murcia, 1997; Montsserrat Carbonel, Sobreviure a Barcelona: dones, pobresa i assistencia al segle XVIII, Barcelona, Eumo Eidorial, 1997.

${ }^{11}$ Vejam-se Maria Antónia Lopes, Mulheres, espaço e sociabilidade. A transformação dos papéis femininos em Portugal à luz de fontes literárias (segunda metade do século XVIII), Lisboa, Livros Horizonte, 1989; Pobreza, assistência e controlo social. Coimbra 1750-1850, 2 vols, Viseu, Palimage Editores, 2000; Protecção Social em Portugal na Idade Moderna, Coimbra, Imprensa Universitária, 2010; Isabel Sá, "Os espaços de reclusão e a vida nas margens", in José Mattoso (dir.), História da vida privada em Portugal, Lisboa, Círculo de Leitores, 2010, p. 276-292; Isabel Drumond Braga, Vivências no feminino-poder, violência e marginalidade nos séculos XV a XIX, Lisboa, Tribuna da História, 2007; Maria de Fátima Reis, "Poder régio e tutela episcopal nas instituições de assistência na época moderna- os Recolhimentos de Lisboa", Laurinda Abreu (ed.), Igreja, caridade e assistência na Península Ibérica (sécs. XVI-XVIII), Lisboa; Edições Colibri/CIDHEUS-EU, 2004, p. 263-274; Isabel Morujão, Contributo para a bibliografia cronológica da Literatura Monástica Feminina portuguesa dos séculos XVII e XVIII, Lisboa, Centro de Estudos de História Religiosa, 1995; "Entre a voz e o silêncio: literatura e espiritualidade nos mosteiros femininos", Rever-Revista de Estudos de Religião, ano 11, n 1 , S. Paulo, (2011), p. 35-54.
} 
outro lado, são menos abundantes os trabalhos existentes sobre recolhimentos para mulheres pecadoras, também porque eram em menor quantidade.

Neste trabalho debruçamo-nos sobre práticas de higiene, doença e morte no recolhimento de Santa Maria Madalena, procurando analisar e entender como se praticava a higiene, se detetava e combatia a doença e se enfrentava a morte. Assim, procuramos saber que práticas de higiene e de saúde pública existiam na instituição? Que importância assumia a água para o seu funcionamento e limpeza? Como se agia perante a doença? Quem eram os curadores? Como se enfrentava a morte e se procurava a salvação da alma?

Pretendemos apreender as vivências desta população encerrada, procurando perceber como se aproximavam da vida do século ou a circunstância particular de ser uma casa de mulheres penitentes condicionava os seus percursos.

No que se refere aos restantes recolhimentos da cidade, todos eles para mulheres virtuosas, conhece-se muito mal o seu quotidiano, com exceção do de Santo António do Campo da Vinha.

\section{A limpeza dos corpos e dos espaços}

Como é do conhecimento geral, os cuidados com a limpeza do corpo vão acentuar-se ao longo do século XVIII. Todavia, já mesmo antes se tomavam medidas para cuidar do corpo e prevenir a doença: resguardar do frio com mais roupa, evitar as correntes de ar, abandonar certos locais em tempo de peste, eram, por exemplo, algumas das precauções tomadas ${ }^{12}$. Estas medidas vão intensificar-se ao longo de Setecentos, assistindo-se em termos particulares e públicos à tomada de medidas para combater a doença.

Em termos públicos, os Municípios trataram de combater os períodos de peste e de doença com maior higiene nas vias públicas, proibindo a circulação de alguns animais nas cidades, como era o caso dos porcos, ordenando a limpeza das fontes e a existência de água corrente, assim como mais higiene nos açougues. Ao mesmo tempo, obrigava-se as pessoas a manterem limpas as portadas das casas, impedindo ainda a entrada de forasteiros nas cidades e vilas, potenciais portadores de doença. Em tempo de peste, as portas da cidade podiam ser também encerradas. Sempre que era necessário intervir, a Câmara de Braga ordenava a limpeza dos espaços públicos, como se verificou em 1726 quando mandou aos moradores da cidade a lavagem das ruas e das frontarias

\footnotetext{
${ }^{12}$ Martin, Dingues, "Health care and poor relief in regional Southern France in the CounterReformation", in Ole Peter G.; Andrew C.; Jon A. (dir.), Health care and poor relief in Counter-Reformation Europe, London, Routledge, 1999, p. 240-279.
} 
das casas e proibiu os residentes do campo de Santa Ana de lançarem os lixos de suas casas e o entulho para o referido campo, sob pena de pagarem uma multa de seis mil réis. Este dinheiro era repartido da seguinte forma: metade era encaminhado para as despesas concelhias e o restante para o acusador. Interditava-se também os residentes do campo de São Sebastião de largarem entulho no local, sendo igualmente multados com o referido montante ${ }^{13}$.

No campo de Santa Ana existiam nesta altura dois recolhimentos (o de Santa Maria Madalena e o da Penha de França) e o convento masculino dos Neris. No ano seguinte, o recolhimento de Penha de França passou a convento por incentivo do arcebispo D. Rodrigo de Moura Teles.

Os maiores cuidados de higiene sentiram-se também nas instituições de reclusão, essencialmente nos hospitais, embora o termo reclusão assuma nestas instituições um caráter diferente do existente nos conventos e recolhimentos. Todavia, em Braga, no hospital de $\mathrm{S}$. Marcos foram crescentes as medidas de higiene no decorrer dos séculos XVII e XVIII ${ }^{14}$, muito embora, o hospital continuasse a ser um lugar pouco limpo, nomeadamente no que se refere à higiene corporal e ao setor das roupas. Deve, no entanto, sublinhar-se o esforço feito para melhorar a instituição neste campo. O mesmo se passava noutros congéneres onde a higiene era cada vez mais valorizada ${ }^{15}$.

Também no recolhimento de Santa Maria Madalena, os estatutos de 1722 previam ações concretas de higiene pessoal e do edifício, assegurando maior limpeza e asseio.

Para o período em estudo, a documentação sobre estas instituições nem sempre permite analisar as preocupações existentes com a limpeza dos espaços, todavia, o regulamento deste recolhimento aponta, em algumas partes, para a necessidade de asseio e limpeza, quer nos espaços comuns, quer nas celas. É curioso verificar como os cuidados a ter com a higiene são demonstrativos de uma crescente preocupação com esta matéria.

Depois de se levantarem, as recolhidas deviam proceder à higiene pessoal nas suas celas, embora os estatutos não mencionem em que consistia. Como se sabe, não existiam espaços particulares para a higiene, sendo no quarto que se levavam algumas partes do corpo. É sabido que durante a Idade Moderna,

${ }^{13}$ Arquivo Municipal de Braga (doravante AMB), Livro das actas de vereação 1726, $\mathrm{n}^{\circ} 40$, fl. 17.

${ }^{14}$ Maria Marta Lobo de Araújo, Memória e quotidiano: as visitas e as devassas ao hospital de S. Marcos de Braga na Idade Moderna, Braga, Santa Casa da Misericórdia de Braga, 2014, p. 114-135.

${ }^{15}$ Paula Sofia C. Fernandes, O hospital da misericórdia de Penafiel (1600-1850), Braga, Universidade do Minho, 2015, tese de doutoramento policopiada. 
o corpo não era lavado e que apenas a cara e as mãos eram sujeitas à limpeza da água ${ }^{16}$. Este facto não significava falta de preocupação com a limpeza ${ }^{17}$. Acreditava-se que a água podia ser prejudicial à saúde, removendo-se, por isso, a roupa, normalmente a camisa, que estava em contacto com as secreções corporais e não se lavando senão algumas partes do corpo. Como refere Georges Vigarello, na Idade Moderna a "higiene das pessoas é a roupa"18. Porém, ainda que sejam vagos, os estatutos do recolhimento apontam para a lavagem do corpo ao referirem que as mulheres "se lavarão enquanto se não tocar ao Exercicio", período em que também tinham de fazer a cama ${ }^{19}$. A cama era feita todos os dias, após se levantarem, devendo igualmente varrer as celas diariamente, fazendo correr o lixo para trás da porta, onde se manteria até ao dia de sábado, data em que era varrido para o corredor e este limpo.

A limpeza tinha calendário e quotidianamente apenas era feita uma parte. Era aos sábados que as recolhidas se entregavam mais afincadamente à higiene da casa, talvez por terem mais tempo para esta atividade.

Para evitar contágio de doenças, exigia-se à “enfermeira” cuidados especiais na limpeza das celas das doentes. As suas camas deviam ser feitas todos os dias e as celas varridas sempre que fosse necessário, de maneira que se mantivessem sempre limpas e bem perfumadas. Cabia à "enfermeira" proceder a estes trabalhos, procurando ervas cheirosas para perfumar o ambiente e afastar os maus cheiros. Procurava-se apagar os maus cheiros e proporcionar bons odores às doentes, combatendo também desta forma a doença.

A limpeza e os bons cheiros integravam conjuntamente com a alimentação o programa da cura, quer em casa, quer nos hospitais ${ }^{20}$, quer ainda nas casas de reclusão. Era importante afastar a doença para que a propagação não ocorresse.

As “companheiras" estavam encarregues de proceder à limpeza do corredor, assim como das escadas que davam acesso ao local de trabalho, no dia referido, tendo horas para desempenhar este serviço. Deviam cumpri-lo antes do toque do sino para irem ao coro. Ou seja, a higiene corporal e a limpeza do edifício

${ }^{16}$ Georges Vigarello, O limpo e o sujo. A higiene do corpo desde a Idade Média, Lisboa, Fragmentos, 1988.

${ }^{17}$ Raffaela Sarti, Casa e Família. Habitar, comer e vestir na Europa da Idade Moderna, Lisboa, Ed. Presença, 2001, p. 326.

${ }^{18}$ Georges, Vigarello, O limpo e o sujo..., cit., p. 66.

${ }^{19}$ Sara F. M. Grieco, "O corpo, aparência e sexualidade" in Arlette Farge; Natalie Z. Davis (dir.), História das Mulheres. Do Renascimento à Idade Moderna, Porto, Afrontamento, 1994, p. 80.

${ }^{20}$ Isabel Sá, "Os hospitais portugueses entre a assistência medieval e a intervenção dos cuidados médicos no período moderno", in Congresso Comemorativo do V Centenário da Fundação do Hospital do Espírito Santo de Évora, Actas, Évora, Hospital do Espírito Santo de Évora, 1996, p. 87-103. 
fazia-se bem cedo, antes de qualquer outra atividade relevante. Devia procederse a este serviço de maneira a não perturbar as tarefas diárias.

As refeições deviam também ser confecionadas com limpeza. Faz-se menção a este assunto, chamando a atenção para as recolhidas atuarem com asseio na cozinha. Esperava-se ainda que as mulheres se comportassem no refeitório com "quietação, paridade e limpeza", por ser um momento solene de reunião de todas, assistindo às leituras em silêncio e portando-se com civilidade à mesa ${ }^{21}$.

Os outros espaços do recolhimento eram também tidos como sítios onde devia imperar um certo asseio. Estava atribuída à regente a tarefa de inspecionar a casa de trabalho, cuidando de averiguar a sua limpeza, devendo zelar para que as mulheres a tivessem asseada e em ordem, devendo varrê-la todas as semanas.

Mas não só o espaço de internamento, também a capela devia estar limpa. Cabia à criada de fora varrer semanalmente a sacristia, bem como lavar a roupa que servia nesse espaço: toalhas e corporais, deviam ser sujeitas a lavagem todas as vezes que fosse considerado necessário, devendo também engomar as referidas peças. As constituições sinodais de Braga, publicadas em 1697, estabeleciam a limpeza das igrejas, sendo determinado penas pecuniárias para quem não cumprisse. A lavagem das roupas, bem como a sua guarda encontravam-se igualmente regulamentadas, de maneira que se preservassem e não levassem descaminho ${ }^{22}$.

Era ainda esta mulher que assumia a responsabilidade de dois em dois dias varrer os coros de baixo e de cima.

A chamada de atenção para a limpeza dos espaços de internamento e da capela reflete a crescente preocupação com o asseio, a que não apenas os prédios, mas também os bens ${ }^{23} \mathrm{e}$ as pessoas passaram a estar sujeitas no decurso do século XVIII. Todavia, também os espaços exteriores passaram a ser considerados. Cabia à "campeira" zelar para que os caminhos da horta e de outros espaços exteriores estivessem limpos e varridos, facilitando a passagem das recolhidas nos pequenos passeios que efetuavam durante o dia. Dar ao espaço exterior uma certa ordem e criar racionalismo na sua utilização significava aprumo e disciplinamento.

${ }^{21}$ Ana M. Xisto Barcía, Mujeres y cultura letrada en la Galicia Moderna ..., cit., p. 95-99.

${ }_{22}$ Constituiçõens Sinodais do arcebispado de Braga ordenadas pello Illustrissimo Senhor Arcebispo D. Sebastião de Matos e Noronha no anno de 1639 e mandadas emprimir a primeira vez pelo Illustrisimo Senhor D. João de Sousa Arcebispo e Senhor de Braga, Lisboa, Na Officina de Miguel Deslandes, 1697, p. 323, 335-336.

${ }^{23}$ Apelava-se à "despertadora" para que tivesse as lâmpadas dos dormitórios sempre limpas e asseadas. 
A forma como a higiene e a limpeza eram tidas em consideração aponta para uma visão global do edifício e do espaço, deixando esta de estar focada num ou noutro pormenor ou sítio. Estamos, no entanto, longe de ver concretizados os objetivos expostos por alguns teóricos portugueses e estrangeiros setecentistas sobre a higiene e a saúde pública ${ }^{24}$.

\section{O abastecimento de água}

Muito importante para o quotidiano da instituição e para as ações de asseio e limpeza era o abastecimento da água e esse foi um dos problemas com que a instituição teve de lidar. Como muitas outras casas particulares, o recolhimento tinha um poço no pátio de onde tirava água para consumo interno. Com necessidade dela para cozinhar, limpeza do edifício e das recolhidas, para a lavagem da roupa e rega da horta, a preocupação para ser abastecido levou as regentes a procurarem auxílio junto do Paço quando o assunto se colocava. As superioras preocupavam-se em criar estruturas eficientes de abastecimento de água a uma casa em crescimento. A água chegava até ao local de ser colhida através de um cano, que custou 49 mil réis, em $1743^{25}$, porém, em 1775 a superiora informava D. Gaspar de Bragança (1758-1789) das obras que tinha em curso no poço do pátio e pedia auxílio para as acabar. Já tinha comprado os alcatruzes e o azeite para os betumes, mas, e como já passara muito tempo, o azeite tinha sido consumido na comunidade, embora ela própria tivesse oferecido "três moedas", dinheiro recebido da entrada de uma porcionista, para a obra. Faltava, no entanto, o restante para que esta se concluísse e essa era a razão que a levava a abeirarse do arcebispo. Para erguer a nora no pátio, precisava da ajuda do prelado, pedindo-lhe que assumisse a restante despesa ${ }^{26}$.

No século XVIII, a modernização e o crescimento da cidade expressaram-se também nas preocupações dos arcebispos relativamente à canalização de águas e à construção de fontes. D. Rodrigo de Moura Teles, D. José de Bragança

${ }^{24}$ Bruno Barreiros, "O discurso higienista no Portugal do século XVIII: tradição e modernidade", in Arte Média e Imagem do Corpo. De Hipócrates ao final do século XVIII, Lisboa, Biblioteca Nacional de Portugal, 2010, p. 129-131.

${ }^{25}$ Museu D. Diogo de Sousa (doravante MDDS), Fundo do recolhimento de Santa Maria Madalena, Livro da despeza 1722-1826, Pasta 1083, fl. 44.

${ }^{26}$ MDDS, Fundo do recolhimento de Santa Maria Madalena, Pasta 1081, não paginado. 
(1741-1756) ${ }^{27}$, e D. Gaspar de Bragança realizaram obras para proporcionar melhor abastecimento de água à população ${ }^{28}$.

$\mathrm{O}$ recolhimento tinha recebido para a obra que tinha em curso alguns donativos das recolhidas, mas como não eram suficientes, recorria-se ao prelado para contribuir com o restante, pois não devia ultrapassar 15 moedas, já com todo o trabalho incluído. O despacho do Paço de 1775, ordenava ao vigário geral da Mitra para contactar o pedreiro Paulo Vidal, o qual já tinha feito a medição e o risco para a obra, pois para além da nora, o projeto integrava também a construção de um tanque e a passagem da água de fora para o recolhimento.

Para que a água chegasse ao recolhimento, vinda do Reduto, foi preciso fazer obras na cerca. A oportunidade que a regente não queria desperdiçar era a de não perder a água que da caixa geral passava num cano que servia o convento da Penha de França, que, como, já referimos, se situava também no campo de Santa Ana. O cano vinha de norte para sul e atravessava a cerca do recolhimento. Os canos podiam correr em locais públicos, como eram as ruas, ou particulares, como o pátio referido e até por "debaixo de casas" 29 .

$\mathrm{Na}$ altura em que a obra se estava a realizar, a regente voltou a contactar o arcebispo para permitir a abertura de uma porta que desse acesso à entrada de lenha e à saída do estrume das cloacas, deixando de ser utilizada a porta do refeitório e da cozinha para fazer transitar os produtos referidos. Era também uma medida de higiene mover o estrume por outro lugar, que não fosse a proximidade da cozinha. $\mathrm{O}$ estrume da instituição era utilizado na horta, mas quando era excedentário era vendido a homens e a mulheres que o pagavam. A superiora descansava o arcebispo ao afiançar que a nova porta não constituía nenhum risco, nem facilitaria a fuga de recolhidas, por já existirem na cerca mais duas portas antes do muro, servindo assim de antecâmaras protetoras ${ }^{30}$. Recordava que a fuga de uma recolhida pela cerca só foi possível porque "dorubou a parede do mesmo recolhimento" "31, o que só terá conseguido com a ajuda de terceiros, certamente. Perante as garantias dadas, foi concedida a

${ }^{27}$ Maria do C. F. Ribeiro; Maria M. Martins, "Contributo para o estudo do abastecimento de água à cidade de Braga na Idade Moderna. O livro da cidade de Braga (1737)”, in Maria M. Martins; Isabel V. Freitas; María Isabel del Val V. (coord.), Caminhos da água. Paisagens e usos na longa duração, Braga, CITCEN, 2012, p. 188-190.

${ }^{28}$ Miguel S. M. Bandeira, O espaço urbano de Braga em meados do século XVIII, Porto, Afrontamento, 2000, p. 150-151.

${ }^{29}$ Maria do C. F. Ribeiro; Maria M. Martins, "Contributo para o estudo do abastecimento de água à cidade de Braga na Idade Moderna..., cit., p. 196.

${ }^{30}$ No recolhimento do Conde, de Coimbra conheceram-se também fugas. Maria Antónia Lopes, Pobreza, assistência e controlo social..., cit., p. 456.

${ }^{31}$ MDDS, Fundo do recolhimento de Santa Maria Madalena, Pasta 1081, não paginado. 
autorização para a referida passagem, sublinhando-se, no entanto, a necessidade de a fazer segura.

D. Gaspar de Bragança concedeu em 1782 autorização às recolhidas para usarem a água encanada que vinha da fonte nova do Reduto ${ }^{32}$, possibilitando-lhes maior autonomia no acesso ao referido líquido.

\section{A doença e a morte}

Contrariamente a outros recolhimentos que possuíam um espaço destinado às doentes, como acontecia, por exemplo, no de Santo António, de Braga, em Santa Maria Madalena esse compartimento não existia ${ }^{33}$. Aqui, as que estavam doentes mantinham-se nas suas celas e eram aí cuidadas por uma companheira, designada pela regente para as auxiliar nas enfermidades. Era a "enfermeira". Tratando-se de uma obra de misericórdia, a nomeada neste lugar devia atuar com brandura e diligência, ou seja, ter um perfil de mulher caridosa, mas simultaneamente robusta fisicamente para poder acudir às que se encontravam com fraca mobilidade. Devia manter as celas limpas e ser diligente na participação aos profissionais de saúde e ao sacerdote, quando necessário. Competia-lhe ao mesmo tempo dosear de forma adequada as visitas às doentes para que estas não fossem importunadas. Como se tratava de um lugar de grande sensibilidade, um dos requisitos que se lhe pedia era que trouxesse "diante dos olhos o merecimento que ha de ter para com Deos no exercido desta obra de miziricordia" ${ }^{34}$, ou seja, fosse cuidadosa com as suas companheiras enfermas.

Desconhecemos as tarefas exatas que estavam atribuídas à "enfermeira" para além das enunciadas. Presumimos também que fosse ela quem administrava as mezinhas às enfermas e lhes servisse as refeições, quando estivessem incapacitadas de as tomarem autonomamente. A alimentação era fundamental para a cura, por isso, não podia ser descurada. Assistiria ainda os profissionais de saúde e consolaria com palavras as que sofriam em suas camas.

Vivendo em clausura, era natural que as mulheres fossem tratadas no espaço em que se encontravam, todavia, em setembro de 1726 uma recolhida saiu de Santa Maria Madalena com autorização do arcebispo para se curar no hospital de

${ }^{32}$ Arquivo Distrital de Braga (doravante ADB), Fundo do Registo Geral, Livro n ${ }^{\circ} 208$, fl. 53.

${ }^{33}$ Manuela Machado, Entre a clausura e o século: o recolhimento de Santo António do campo da Vinha sob a administração da Misericórdia de Braga (séculos XVII-XVIII), Braga, Universidade do Minho, 2014, dis. de mestrado policopiada.

${ }^{34}$ MDDS, Fundo do recolhimento de Santa Maria Madalena, Livro dos antigos estatutos, Pasta $^{\circ} 36$, não paginado. 
S. Marcos. Seria o medo do contágio que levou a tomar esta atitude? A gravidade da situação? Sabemos que em determinados momentos apenas alguns locais e ruas foram tocados por certas doenças. O registo do facto não menciona a doença de que esta padecia e a necessidade de ir para o hospital, sabe-se somente que a regente pagou 2.960 réis a S. Marcos pelo seu tratamento ${ }^{35}$. Porém, a ordem para limpar a cidade saída da Câmara e especialmente o campo de Santa Ana parece indiciar a existência de peste. Como a regra era serem assistidas dentro de portas, que razões teriam levado o arcebispo a autorizar a trasladação desta mulher para S. Marcos? Estaria doente de sífilis? Esta era uma outra possibilidade. A procura deste tratamento era muito grande, levando a Santa Casa a abrir as referidas enfermarias mais do que uma vez durante os períodos de tratamento. $\mathrm{O}$ exercício da prostituição expunha parte das mulheres de Santa Maria Madalena a vários perigos, como era o da sífilis, por isso, quando a suspeita se levantava no momento de ingresso, as interessadas eram inspecionadas para se verificar do seu estado. Cabia ao médico averiguar e emitir parecer escrito.

Sempre que eram assistidas no recolhimento, as mulheres doentes eram alvo de atenção particular, desde logo alimentar ${ }^{36}$. Desconhece-se os produtos adquiridos, mas sublinha-se a particular atenção dada a esta mulher que se encontrava doente.

A saída e a entrada de recolhidas para se tratarem fora do recolhimento aconteceu com alguma regularidade ao longo do século XVIII ${ }^{37}$, como, aliás, se verificou em outras instituições femininas de clausura ${ }^{38}$.

Embora os primitivos estatutos não contemplassem a existência de um cirurgião, referindo somente o médico e o sangrador, o certo é que ele existiu desde sempre. Logo após a abertura do recolhimento, o arcebispo fundador dotou-o de profissionais de saúde, estabelecendo contratos no início do mês de maio de 1722 com um sangrador, um cirurgião e um médico. Os visados ficaram providos nos partidos referidos até o arcebispo cessar o contrato. Nesses documentos cada um era elogiado pelas suas competências técnicas e pelas informações recolhidas, sendo valorizada também a experiência. Estabelecia-se ainda o salário a ganhar, o qual era pago aos quartéis pela Mitra.

${ }^{35}$ MDDS, Fundo do recolhimento de Santa Maria Madalena, Pasta 1083, fl. 19.

${ }^{36}$ MDDS, Fundo do recolhimento de Santa Maria Madalena, Pasta 1083, Livro do de despeza de 1722 a 1826, fl. 1 .

${ }^{37}$ MDDS, Fundo do recolhimento de Santa Maria Madalena, Livro de contas do legado pio que instituio de Catherina Pinheiro para convertidas, Pasta 1089, fl. 16v.

${ }^{38}$ Ricardo Manuel Alves Silva, Casar com Deus: vivências religiosas e espirituais femininas na Braga moderna, Braga, Universidade do Munho, 2012, tese de doutoramento policopiada. 
Com a assinatura do tratado, os profissionais referidos entraram de imediato em funções ${ }^{39}$.

A rapidez com que o arcebispo nomeou estes profissionais de saúde para assistir na doença as recolhidas é bem elucidativa do investimento por si feito na instituição, uma vez que urgia cuidar deste aspeto, tendo em conta as características do recolhimento.

Muitos dos profissionais de saúde que trabalhavam no recolhimento, exerciam também no hospital de S. Marcos da cidade. O Dr. Jerónimo Saraiva exerceu nesse estabelecimento em 1686 e 1692 e mais dois anos, entre 1694 e 1695, ganhando na altura 5.000 réis anualmente. Também o Dr. António Fernandes do Vale trabalhou no mesmo hospital, devendo ser já pessoa com alguma idade quando assistiu no recolhimento, porquanto morreu em 1753. Os Drs. Caetano Luís Pereira e Caetano José de Sampaio Peixoto, médicos da cidade, exerceram em S. Marcos em simultâneo com o trabalho do recolhimento ${ }^{40}$. Já sobre o médico António José Lopes sabemos apenas que se ocupou também dos doentes do hospital, mas desconhecemos em que período.

A importância de possuir médicos próprios era grande numa instituição de clausura. No caso das mulheres que vinham com a honra manchada era ainda fundamental para serem examinadas previamente ao ingresso. Procurava-se saber se eram portadoras de doenças contagiosas que pudessem pôr em perigo a comunidade. Devido ao pecado da carne, podiam contrair doenças sexualmente transmissíveis, sendo, por isso, alvo da maior vigilância. Quando se tratava de um caso desses e sobretudo se havia suspeitas, a regente solicitava os serviços do médico para a examinar e pronunciar-se ${ }^{41}$. A sífilis, doença em progressão na Idade Moderna e muito associada a uma vida dissoluta era temida e podia colocar o recolhimento em alerta, exigindo cuidados especiais de despiste ${ }^{42}$. Por mais do que uma vez o médico foi chamado a observar e a pronunciar-se sobre algumas das que solicitaram admissão às do número. O clínico podia também pronunciar-se sobre as capacidades físicas da peticionária, sublinhando num

${ }^{39}$ ADB, Registo Geral, Livro no 56, fls. 211v.-212v.

${ }^{40}$ Maria de F. Castro, A Misericórdia de Braga. A assistência no hospital de S. Marcos, vol. IV, Braga, Santa Casa da Misericórdia de Braga e Autora, 2008, p. 359-365.

${ }^{41}$ ADB, Fundo do Registo Geral, Livro no 166, fls. 310v.-312.

${ }^{42}$ Robert J., "Syphilis and confinement" in Detlef Junker; S. Daniel Mattern (eds.), Institutions of Confinement: Hospitals, Asylums and Prisions in Western Europe and North America: 15001950, Cambridge; University Press, 1996,pp. 97-115. A propósito do tratamento da sífilis em Braga no hospital de S. Marcos leia-se Maria Marta Lobo de Araújo, "O tratamento das boubas no hospital de S. Marcos de Braga na Época Moderna” in María José Pérez Á.; Maria Marta Lobo de Araújo (coords.), La respuesta social a la pobreza en la Península Ibérica..., cit., p. 31-54. 
caso a falta de robustez para o trabalho e as restantes tarefas diárias, bem como eventuais gravidezes das peticionárias. Era preciso acautelar tudo, quando se sabia que algumas tinham uma vida não recomendável. Estamos perante uma instituição religiosa que procurava alterar a vida das mulheres e devolvê-las à sociedade como mulheres arrependidas.

Apesar de a sífilis ser grave e de se alastrar com frequência, outras doenças eram igualmente temidas, como era o caso da tuberculose ${ }^{43}$. Em 1775 morreu uma recolhida de tísica na sua cela. Posteriormente, este mesmo espaço entrou em obras, não se especificando o tipo de remodelação que foi efetuada. Por esta altura, existia na cidade um grande surto desta doença, facto que levou o hospital de S. Marcos a construir uma enfermaria para tuberculosos três anos após.

Desconhecemos como lidou o recolhimento com esta companheira que contraiu a doença, mas o certo é que a manteve até à morte dentro de portas.

De acordo com a sintomatologia da doença, o recolhimento chamava o profissional de saúde adequado. Para questões de Medicina, requisitava os serviços do médico. A informação que possuímos sobre os que assistiram em Santa Maria Madalena é muito parca e diz respeito apenas a alguns. Sobre Caetano José de Sampaio Peixoto é referido que era aprovado pela universidade de Coimbra e que também ocupava o partido dos pobres da cidade, pago pela Mitra. Alguns arcebispos mantiveram ao longo da sua prelatura profissionais de saúde pagos pela Mitra para tratar pobres em suas casas ${ }^{44}$. O referido médico foi provido em simultâneo nos dois partidos, mas ressalvou-se a necessidade de ser diligente na assistência às recolhidas ${ }^{45}$.

A análise do livro dos salários demonstra que nem sempre existiram contratos com o médico, sangrador e cirurgião. Em determinados momentos fica-se com a sensação de que só lhes era pago o serviço realizado. Porém, na segunda metade de setecentos e no século seguinte a instituição mudou de atitude e manteve contratos certos com os referidos profissionais de saúde, pagando com regularidade os seus salários. Esta situação esteve provavelmente associada ao facto da cidade ter conhecido em finais de setecentos várias doenças, principalmente na última década ${ }^{46}$.

${ }^{43}$ Abilio G. Marques, A guerra á tuberculose, Porto, Escola Médico Cirurgica, 1901, p. 28.

${ }^{44}$ D. Rodrigo de Moura Teles foi um deles. Leia-se Boaventura Maciel Aranha, Epitome da vida, e virtudes do excelentissimo senhor D. Rodrigo de Moura Telles, arcebispo de Braga Primaz das Hespanhas, Lisboa, Officina Pinheirense, 1743, p. 632-637.

${ }^{45}$ ADB, Fundo do Registo Geral, Livro no 139, fl. 123.

${ }^{46}$ João P. Abreu, Em Braga de 1790 a 1805. D. Frei Caetano Brandão: um reformador contestado, Braga, UCP/FTB; CMPB, 1997, p. 164-165. 
A partir do século XVIII, a medicina passou a recomendar para certas doenças a frequência de termas e banhos de mar. Hospitais e instituições de reclusão mandavam os seus doentes para estas curas e o recolhimento de Santa Maria Madalena seguiu também as prescrições médicas. Todavia, as interessadas tinham de solicitar autorização ao arcebispo e no final do tratamento deviam regressar à instituição, embora algumas aproveitassem a oportunidade e não voltaram ${ }^{47}$.

Com a cidade tomada pelos franceses e cheia de militares, algumas preferiram manter-se em casa, mais distantes da confusão em que Braga tinha caído ${ }^{48}$. Por outro lado, o tempo era também desfavorável à clausura. Se muitas mulheres eram internadas em Santa Maria Madalena contra vontade e viviam vidas que não desejavam, qualquer pretexto servia para o abandonarem.

Para além do médico, os serviços do cirurgião eram também requeridos quando necessário.

A idade dos homens que exerciam em Santa Maria Madalena era provavelmente um fator a ter em consideração na altura de os contratarem. Procuravam-se homens com experiência em termos profissionais, mas também com alguma idade, sinónimo de amadurecimento e assento. A partir de determinada altura, o cirurgião desempenhou também os serviços anteriormente atribuídos ao médico.

A ocupação dos dois cargos aconteceu em vários hospitais e decorre da imagem destes profissionais de saúde junto das populações, mas não só! A indefinição de fronteiras entre a sua área de competência e a dos sangradores justificou a acumulação de funções ${ }^{49}$, ainda que de forma temporária.

Os sangradores estavam encarregues das sangrias e de lançar as sanguessugas, mas podiam também tirar dentes, ou seja, proceder a pequenas cirurgias. Mas a sua principal ocupação era o trabalho com a lanceta, fazendo sangrias. Ocupavam o lugar mais baixo na hierarquia dos profissionais de saúde que davam apoio a Santa Maria Madalena e deixaram de ser contratados a partir de 1812 .

${ }^{47}$ MDDS, Fundo do recolhimento de Santa Maria Madalena, Pasta 1036, documento avulso, não paginado.

${ }^{48}$ José V. Capela; Henrique M., Rogério Borralheiro, O heróico patriotismo nas províncias do Norte. Os concelhos na Restauração de Portugal de 1808, Braga, Casa Museu de Monção, 2008, p. 121-144.

${ }^{49}$ Laurinda Abreu, “A organização e regulação das profissões médicas no Portugal Moderno: entre as orientações da Coroa e os interesses privados" in Arte Média e Imagem do Corpo..., cit., p. 112. 
Quando não se vencia a doença, a morte era inevitável. Os últimos momentos da vida destas mulheres eram passados na cela, onde morriam. Depois de mortas, as recolhidas eram depositadas no coro baixo, onde eram veladas. Todavia, em pequeno número, é certo, mas houve quem tivesse o seu velório na capela, como aconteceu com Paula Rebelo, em 1812.

Nos momentos que aproximavam a morte, a regente e as recolhidas abeiravam-se da que estava para partir, ajudando-a a bem morrer com orações e consolos espirituais. $\mathrm{O}$ temor imposto pela morte levava a que estes momentos fossem vividos em coletivo ${ }^{50}$. Depois, era colocada na tumba e levada pelas companheiras para o coro baixo.

$\mathrm{O}$ estudo da morte no recolhimento é dificultado pela falta de fontes. $\mathrm{O}$ facto de existirem poucos testamentos de recolhidas e de só termos estudado alguns registos de óbito limita-nos a análise, sobre os cultos venerados, os santos da proteção de cada uma, a forma como sentiam e viviam a morte, enfim informações que nos ajudassem a compreender o universo mental e religioso destas mulheres, mas também o lado prático da morte. Que hábito escolhiam? Onde queriam ser sepultadas? Quantas missas instituíam? Como dispunham da herança, quando a tinham? Quem beneficiava dela? Que relações mantinham com as suas companheiras de muitos anos e como estas se repercutiam no momento da passagem?

Apesar destas nossas preocupações, a análise das fontes consultadas prova de forma muito clara a pobreza em que vivia a maioria destas mulheres.

Habituadas a envergarem o hábito de terceiras franciscanas, foi com ele que muitas quiseram partir, acreditando nos seus benefícios espirituais. Os hábitos franciscanos eram os mais pedidos, precisamente por recaírem neles maiores benefícios e, dessa forma, ser mais fácil alcançar a salvação da alma ${ }^{51}$.

Em Braga, existia no século XVIII um interessante mercado de confeção e venda de hábitos, principalmente da ordem franciscana, para serem usados no dia-a-dia e na partida da vida terrena. Estas peças eram confecionadas em alguns conventos femininos da respetiva Ordem, tendo no convento dos Remédios, provavelmente sido o centro de maior produção ${ }^{52}$.

${ }^{50}$ Antonia M. D’Arleux, "Arte de bien morir en los conventos femeninos del siglo XVII", in María Isabel Viforcos M.; Jesús Paniagua P. (coords.), Actas del I Congreso Intrenacional del Monacato Femenino en España, Portugal y América, 1492-1992, T. II, León, Universidad de León, 1993, p. 91-104.

${ }^{51}$ Domingo González Lopo, Los comportamientos religiosos en la Galicia del Barroco, Santiago de Compostela, Xunta da Galicia, 2002.

${ }^{52}$ Ricardo Silva, "O uso da mortalha franciscana em Braga na Época Moderna”, em publicação. Agradeço ao autor a possibilidade de poder ler e citar este trabalho antes da sua publicação. 
Quando se presenciava a morte, era altura de a tomar em maior atenção e pedir o que se desejava para este momento final. Teresa de Jesus Maria Oliveira declarou por escrito ter vontade de ser acompanhada no estado de moribunda pelo padre Manuel Carvalho, para a ajudar a bem morrer ${ }^{53}$. Pediu também que António da Caridade lhe tratasse do enterro e que o servo da confraria de São Vicente, de quem era irmã, chamasse os irmãos para a acompanharem à última morada. A este serviçal deixou uma "coroa" e a António da Caridade duas pelo serviço prestado ${ }^{54}$. A assistência espiritual neste momento decisivo era fundamental para o ultrapassar. Com o sacerdote à cabeceira a aconselhá-la a sofrer com resignação, a arrepender-se dos pecados, a pedir perdão a Deus, a aceitar o seu destino e a implorar pela sua alma, a morte era enfrentada com maior segurança e tranquilidade. Este foi um caso excecional, porque a maioria das estudadas nada possuía ou tinha parcos bens. Ao contrário, tinham dívidas umas às outras ou à comunidade ${ }^{55}$. Mas é ainda possível analisar as relações que mantinham dento da instituição, alguns bens que possuíam nas suas celas, as preferências familiares e a ligação ao recolhimento. Com fraca capacidade para o trabalho, por serem velhas ou sofrerem de achaques, muitas mulheres experimentavam a dureza da pobreza no final da vida. Acontecia sobretudo com as mulheres sós ou quando eram viúvas, principalmente por estarem isoladas e desamparadas ${ }^{56}$. Os móveis ou outro tipo de património que tinham eram modestos, estando em linha com outros recolhimentos estudados ${ }^{57}$.

A cerimónia dos acompanhamentos era determinada pelas posses de cada uma. Por isso, o número de padres presentes variava de acordo com a sua capacidade financeira. $\mathrm{O}$ volume era muito variado e a cerimónia até podia contar apenas com o sacerdote da paróquia de São Vítor, como aconteceu com no funeral de Maria Josefa, em $1742^{58}$. Quase sempre o número de sacerdotes que marcava presença no funeral não ultrapassava os 10, mas este volume era variado. Nem sempre esse número faz transparecer a capacidade financeira da falecida, pois vários padres participavam gratuitamente nestas cerimónias, como se menciona nos registos de óbito. A análise de 49 registos de óbito

${ }^{53}$ Ana F. L. Felix Costa, Assistência ao doente moribundo no século XVIII, Porto, Universidade Católica Portuguesa, 2012, p. 41-43, dis. de Mestrado policopiada.

${ }^{54}$ MDDS, Pasta 1036, documento avulso, não paginado.

${ }_{55}^{5}$ ADB, Fundo Paroquial, Livro de óbitos da freguesia de São Vitor 1751-1776, fl. 191.

${ }^{56}$ Jean-Pierre Gutton, Naissance du vieillard, Paris, Aubier, 1988, p. 62-86.

57 Maria Adília Fernandes, O recolhimento de Santo António do Sacramento de Torre de Moncorvo (1661-1814), Coimbra, Palimage Editores, 2014, p. 301-303.

${ }^{58}$ ADB, Fundo Paroquial, Livro de óbitos da freguesia de São Vítor 1737-1751, fl. 104; Livro de óbitos da freguesia de São Vitor 1811-1821, fl. 82. 
possibilitou conhecer a incapacidade destas mulheres de arrolarem para o momento confrarias, mais padres e mandar celebrar missas.

O pedido de confrarias para acompanhar à última morada alargava a rede de instituições protetoras, com a finalidade de rezarem pela alma da falecida. Ao mesmo tempo, com a sua presença conferiam maior solenidade ao ato ${ }^{59}$. Todavia, era necessário pertencer-lhe ou ter dinheiro para lhes pagar, o que não acontecia com as recolhidas estudadas. Destas, só apenas duas contaram com acompanhamentos para além das que teriam sido levadas à cova pela instituição de São Gonçalo, confraria sediada na capela do recolhimento e a que pertenciam.

Se, por um lado, os acompanhamentos eram úteis a quem os solicitava, por outro, também revertiam a favor das próprias confrarias, desde logo, por ser um serviço pago, mas também por lhes conferir visibilidade. Para as instituições de maior envergadura era ainda uma forma de ostentarem a sua capacidade mobilizadora e organizativa, servindo-se do pretexto para evidenciar a sua força social ${ }^{60}$.

Assistir espiritualmente os seus confrades na hora da morte, fazer-lhes o acompanhamento e o enterro e interceder pelas suas almas com missas e responsos era o principal objetivo das confrarias. Todas se esmeravam nestas ocasiões para honrarem os seus confrades mortos, mas também os que pagando, chamavam os seus serviços. Algumas destas instituições, ajudavam ainda materialmente a bem morrer os seus membros. Conhecendo a situação de partida em que estes se encontravam, iam de forma rotativa para a sua cabeceira, rezando, aconselhando-lhes os sacramentos e lembrando-lhes que perdoassem as ofensas recebidas em vida ${ }^{6}$.

A maioria das recolhidas era levada até ao local de sepultura numa tumba que depois regressava à instituição. $\mathrm{O}$ uso do caixão surge em Braga na segunda metade do século XVIII, mas são muito raras as pessoas que podem pagar este móvel fúnebre, sendo, por isso, corrente o uso da tumba ${ }^{62}$.

Os sufrágios que alcançaram maior popularidade no pós-Trento foram as missas, invocando principalmente a alma do legatário e/ou dos seus familiares

${ }^{59}$ Ana C. Araújo, A morte em Lisboa: atitudes e representações 1700-1830, Lisboa, Editorial Notícias, 1997, p. 338.

${ }^{60}$ Tiago Ferraz, "Acompanhar ao outro mundo: a morte nas confrarias de Braga no século XVIII. Estudo preliminar”. CEM, nº 3 (2012) p. 169.

${ }^{61}$ Tomás A. Mantecón Movellán, Contrarreforma y religiosidad popular en Cantabria, Cantabria, Asambea Regional de Cantabria, 1990, p. 88-105.

${ }^{62}$ Tiago Ferraz, A morte e a salvação da alma na Braga Setecentista, Braga, Universidade do Minho, 2013, tese de doutoramento policopiada. 
próximos. O temor do juízo final levou o homem moderno à junção de preces, na tentativa de alcançar a salvação ${ }^{63}$.

As recolhidas contavam com 10 missas mandadas celebrar pela instituição por cada falecida, porém as que pertenciam a confrarias beneficiavam do número de sufrágios que cada uma dessas instituições lhe disponibilizava. Mas as que tinham algumas condições financeiras cuidavam de pôr a sua alma no caminho da salvação, contando com a intercessão dos vivos, determinando missas e ofícios pela sua alma.

As fracas possibilidades económicas destas mulheres levaram-nas a canalizarem os seus recursos para atenderem quase exclusivamente a sua alma, deixando no esquecimento a de alguns familiares próximos, como era vulgar surgirem nos testamentos ${ }^{64}$.

Quando existiam algumas posses, cumpriam-se os usos e os costumes da freguesia, que consistiam na celebração de dois ofícios de vinte padres cada e 57 missas rezadas. Se fosse pessoa nobre eram-lhe celebradas mais duas missas cantadas. Talvez por este motivo, apenas foi referido num registo de óbito o cumprimento de tais usos e costumes e muito amiudadamente feita menção ao seu incumprimento devido à pobreza da falecida.

Com falta de dinheiro, algumas recolhidas tentaram arranjar recursos para pagar algumas missas com os poucos haveres que possuíam, deixando o encargo à regente de os vender para o efeito. O número de missas a celebrar ficava nestes casos dependente do dinheiro conseguido com a venda dos bens, tal como acontecia com alguns testadores dos grupos sociais mais desfavorecidos que pediam as missas possíveis, de acordo com a herança deixada ${ }^{65}$.

As relações que se estabeleciam dentro da instituição aproximavam ou afastavam as mulheres ${ }^{66}$. Porém, era através das sociabilidades estabelecidas dentro de portas que se conhecia a vida de umas e de outras, sendo certo que alguns assuntos ficariam num círculo muito restrito, como seria natural. Era,

${ }^{63}$ Francisco J. Lorenzo Pinar, "El comercio de la muerte en la Edad Moderna: el caso de Zamora" in Muerte, Religiosidd y Cultura Popular, siglos XIII-XVIII, Saragoza; Eliseo Serrano Editor, 1994, p. 435.

${ }^{64}$ ADB, Fundo Paroquial, Livro de óbitos da freguesia de São Vitor 1811-1821, fl. 82v.

${ }^{65}$ Manuela M. Rodrigues, "Morrer no Porto: piedade, pompa e devoções. Alguns exemplos das freguesias da Sé, Santo Ildefonso e Campanhã (1690-1724)" in Colóquio Internacional do Barroco. Actas, vol. I, Porto, Reitoria da Universidade do Porto, 1991, p. 329.

${ }^{66}$ Maria Antónia Lopes, "Repressão de comportamentos femininos numa comunidade de mulheres-uma luta perdida no Recolhimento da Misericórdia de Coimbra (1702-1743)", Revista Portuguesa de História, tomo XXXVII (2005) p. 189-229; António Magalhães, "Pouco importa ter sangue nobre e ser de procedimento vil": mulheres em conflito no recolhimento de S. Tiago (século XVIII)", Estudos Regionais, nº 6, II série (2012) p. 167-177. 
por conseguinte, no microcosmos das relações de cada uma que se resolviam as situações mais problemáticas. Como nem sempre conseguiam pagar o que deviam, na hora da morte, algumas dessas dívidas foram perdoadas, principalmente quando se tratava de casos de pobreza, como aconteceu com D. Isabel de São José, que por ter morrido muito pobre, o pároco de São Vítor perdoou-lhe os direitos paroquiais. Esta recolhida tinha já penhorado os dois pares de brincos que possuía para continuar a ser sustentada pela instituição.

Viver neste recolhimento significou quase para todas as que lá morreram ficar enterradas no coro baixo. Poucas foram as que foram sepultadas na capela de São Gonçalo, talvez porque era preciso pagar 200 réis para aceder a uma sepultura na capela e nem todas eram possuidoras dessa quantia.

A importância que era dada ao local de sepultamento ganhava relevo nos testamentos, quando se expressava o desejo de ser enterrado num lugar determinado. Quem podia tinha sepultura familiar e nesse caso a vontade era, normalmente, a de se juntar aos seus. Outros, escolhiam não apenas a igreja, mas também o sítio dentro dela onde queriam permanecer para sempre. As igrejas eram locais muito hierarquizados, correspondendo a cada sítio preços diferenciados. Só esta razão limitava as opções dos que possuíam menos, pois tinham que se resignar com o local correspondente às suas possibilidades financeiras.

Apesar de a regra ser essa, houve também quem não desejasse a sua última morada no recolhimento e preferisse a igreja de Nossa Senhora a Branca, vizinha do recolhimento, a igreja de São Vicente, por ter ligações à confraria de São Vicente, e o convento do Pópulo, por ter relações familiares a essa instituição. Como se constata as relações com o exterior podiam condicionar a última morada. Quem não as tinha e não podia pagar sepultura fora, resignava-se a ficar em Santa Maria Madalena para sempre.

\section{Apontamentos finais}

A temática por nós escolhida nem sempre é abordada nos trabalhos sobre instituições congéneres e só foi possível analisá-la no recolhimento de Santa Maria Madalena com o cruzamento de fontes. O investimento feito nos profissionais de saúde são a prova de como a saúde das internadas era uma questão relevante.

Considerado o caráter desta instituição, manter regras de higiene e de saúde pública era fundamental para não fazer perigar a saúde de todas as internadas. Por isso, os primeiros estatutos conferem desde logo alguma visibilidade a práticas de higiene corporal e do próprio edifício. 
Era necessário cuidar para que a doença não se instalasse e propagasse, razão que levou o arcebispo instituidor a manter contrato com profissionais de saúde.

Se muitas mulheres após terem cumprido o programa de penitência a que se sujeitavam, regressavam à sociedade, muitas outras permaneceram institucionalizadas até à morte, vivendo vidas, por vezes, conflituosas e pobres. A pobreza é talvez o traço mais marcante que sobressai do estudo dos registos de óbito, mas também dos livros de receitas e despesas. Quem tinha de pagar a sua estadia e não tinha retaguarda familiar que a assegurasse, ficava dependente de alguns bens que possuía e que normalmente penhorava para se alimentar e vestir. Este era normalmente o percurso de muitos velhos. Quando crescia a idade e diminuíam as posses e as força para trabalhar, a pobreza era uma forte possibilidade. Poucos padres, poucas missas e acompanhamentos muito modestos, com sepulturas quase sempre no coro de baixo são as características que sobressaem do funeral da maioria das que ficaram para sempre em Santa Maria Madalena, demonstrando a pobreza em que viviam e a impossibilidade de poderem equacionar outras soluções.

Assim, pensamos que o nosso trabalho pode constituir um contributo para o estudo das práticas de higiene e de saúde nos espaços de reclusão feminina e particularmente no que diz respeito aos recolhimentos. 
